\title{
Turismemorfosis: Tahapan selama seratus tahun perkembangan dan prediksi pariwisata Bali
}

\author{
I Putu Anom, Ida Ayu Suryasih, Saptono Nugroho, I \\ Gusti Agung Oka Mahagangga \\ Universitas Udayana \\ Email: iputuanom@yahoo.com
}

\begin{abstract}
Bali Tourism has grown for the hundred years, but there has never been a mapping of its developmental stages and its future predictions. This article examines the development of tourism in Bali in the past, present, and future predictions, as well as discourse in each stage. Data were collected by literature study, observation, and in-depth interviews with diachronic informants. The main theory used is critical evolution and genealogy. This article offers a model of tourismemorphosis as a stage of tourism development along with its paradigms including the introduction stage, reaction stage, institutional stage, and compromise stage. The prediction of future Bali tourism development is to remain at the compromise stage with the transtourism paradigm that is paradigm with the effort of adjusting all tourism components to respond to the big and rapid changes of tourism globally. Always compromise, Bali tourism stakeholders in the future are still demanded to be creative in the future, customary government, market dynamics, IT development, customs, and religious rituals to survive or even move forward.
\end{abstract}

Keywords: Bali tourism, tourismemorphosis, paradigm, compromise, transtourism

\begin{abstract}
Abstrak
Pariwisata Bali sudah berkembang hampir seratus tahun, namun belum pernah ada pemetaan atas tahap-tahap perkembangannya serta prediksi masa depannya. Artikel ini mengkaji perkembangan pariwisata di Bali pada masa lalu, masa kini, dan prediksi masa depan, serta diskursus dalam setiap tahapannya. Data dikumpulkan dengan studi pustaka, observasi, dan wawancara mendalam dengan para informan. Teori utama yang digunakan adalah
\end{abstract}


evolusi kritis dan geneologi. Artikel ini menawarkan model turismemorfosis sebagai tahap perkembangan pariwisata beserta paradigmanya meliputi tahap pengenalan, tahap reaksi, tahap pelembagaan, dan tahap kompromi. Prediksi pembangunan pariwisata Bali masa depan adalah tetap berada pada tahap kompromi dengan paradigma transturisme, yaitu paradigma dengan upaya penyesuaian segenap komponen pariwisata menyikapi perubahan yang besar dan cepat dari pariwisata secara global. Selalu kompromi, stakeholder pariwisata Bali ke depan tetap dituntut kreatif menghadapi kebijakan pemerintah, dinamika pasar, perkembangan IT, adat-istiadat, dan ritual keagamaan untuk tetap mampu bertahan atau bahkan semakin maju melangkah ke depan.

Kata kunci: pariwisata Bali, turismemorfosis, paradigma, kompromi, transturisme

\section{Pendahuluan}

Dariwisata Bali bermula sejak awal tahun 1900-an, berarti sampai 1 tahun 2010-an ini, usianya sudah melebihi seratus tahun. Meski usianya sudah satu abad lebih, belum pernah ada kajian yang memetakan bagaimana tahap-tahap perkembangannya. Berdasarkan kondisi tersebut maka penting untuk dipahami bagaimana perkembangan kepariwisataan di Bali dan paradigma pariwisata Bali masa lalu, masa kini dan masa yang akan datang? Pemahaman perkembangan kepariwisataan di Bali pada masa lalu, masa kini beserta paradigmanya masing-masing dan prediksi di masa depan akan membantu para pemikir, stakeholders, birokrat, praktisi pariwisata dan masyarakat untuk dapat mengambil kebijakan maupun keputusan dalam perencanaan-pengembangan kepariwisataan. Selain itu, kajian ini diharapkan dapat mengisi gap pengetahuan kita terhadap sejarah perkembangan pariwisata Bali satu abad pertama.

Artikel ini adalah hasil penelitian yang berupaya melihat perkembangan kepariwisataan Bali berdasarkan field research dan studi pustaka. Mengacu kepada pendekatan sejarah terhadap pariwisata dari Raharjo dan Munandar (1998) yang dimodifikasi dalam periodisasinya sesuai hasil temuan di lapangan. Jika Raharjo dan Munandar (1998) mengemukakan tahap 
perkembangan pariwisata di Bali mulai dari tahap pengenalan, tahap reaksi, dan tahap pelembagaan, artikel ini berdasarkan hasil penelitian menetapkan titik waktu yang berbeda pada tiaptiap tahapan tersebut dan menambahkan satu tahapan baru sesuai dengan temuan. Artikel berupaya mengungkap diskurus yang mengemuka, institusi, tokoh yang paradigma dan problematika pada masing-masing tahapan.

\section{Teori dan Metode}

Artikel ini dilandasi oleh serangkaian konsep dan teori dari para ahli yang melihat aspek positif dan aspek negatif pariwisata Bali (Pitana, 2002), pariwisata budaya (cultural tourism) dan budaya pariwisata (touristic culture) (Geriya, 2003), paradigma sebagai tempat berpijak dalam melihat suatu realitas (Ritzer, 1975 dalam Karsidi 2001), periodisasi dalam ilmu sejarah (Nordholt, Purwanto dan Saptari, 2008), mediamorfosis sebagai proses diakronik (Fidler, 2003) yang menjadi inspirasi dalam artikel ini, evolusi paradigmatik (Wijayanto, 2013), dan teori genealogi sebagai diskursus, institusi, dan ketokohan (Foucoult, 1954, dalam Arief, 2014).

Penelitian menggunakan metode penelitian kualitatif (Moleong, 2005), sumber data, yaitu data primer dan data sekunder, dengan jenis data adalah data kualitatif dan data kuantitatif (Sugiyono, 2005). Teknik pengumpulan data adalah teknik observasi, teknik wawancara mendalam yang dikombinasi dengan dan studi pustaka (Sugiyono, 2005; Bungin, 2003). Teknik penentuan informan dengan menggunakan purposive sampling (Sugiyono, 2005). Teknik analisis data menggunakan analisis data kualitatif terdiri dari beberapa alur yaitu komparasi data, verifikasi, penyajian data dengan argumentasi dan interpretasi memakai kerangka budaya masyarakat setempat (Miles dan Huberman,1992). Interpretasi data menggunakan teknik hermeneutika (Sugiharto, 1996).

\section{Tahap-tahap Perkembangan Pariwisata}

Tahapan perkembangan pariwisata Bali dalam seratus tahun disusun dengan melihat empat kriteria yaitu dikursus, institusi, tokoh, dan paradigma dan problematika. Keempat unsur itulah yang menjadi penanda penting setiap periode. Hasil penelitian menunjukkan tahap perkembangan pariwisata Bali dilihat dari 
tahap pengenalan (1902-1913), tahap reaksi (1914-1938), tahap pelembagaan (1950-2017). Tahap Pelembagaan ini dibedakan menjadi empat tahapan yaitu Pelembagaan I (1950-1968), tahapan Pelembagaan II (1969-1990), dan tahapan Pelembagaan III (19912011), dan diperoleh tahap terakhir yang disebut sebagai tahap kompromi (2012-2017) sebagai suatu tahap perkembangan pariwisata yang sedang berjalan ke depan.

Prediksi kelanjutan dari tahap kompromi tidak menunjukkan tahapan baru, hanya dalam perkembangan pariwisata Bali di masa depan akan memiliki paradigma yang disebut sebagai transturisme. Paradigma transturisme dipandang akan menjadi "ice breaker" berbagai problematika kepariwisataan Bali masa depan. Kompromi menjadi pendekatan yang dikedepankan oleh stakeholder pariwisata Bali dalam mengusung pariwisata budaya, namun selalu kreatif menghadapi perubahan-perubahan yang terjadi. Tradisi, adatistiadat, dan ritual keagamaan akan tetap lestari, keharmonisan akan selalu terjaga sepanjang agama Hindu sebagai pondasi utama adat-istiadat di Bali masih dipegang teguh.

Penetapan tahapan pengenalan (1902-1913) atas dasar kedatangan turis Eropa pertama Heer H. van Kol yang secara sadar melakukan perjalanan untuk berwisata dan menuliskan pengalamannya ke sebuah buku. Tahap reaksi (1914-1938) ditetapkan berdasarkan pada tahun 1914 mulai dibuka agen perjalanan di Bali yang menandakan sudah ada wisatawan datang berkunjung ke Bali. Penetapan tahap Pelembagaan I (1950-1968) atas dasar pemerintah Republik Indonesia sudah mulai mapan secara politik internasional dan mulai fokus kepada pembangunan dalam negeri. Tahap Pelembagaan II (1969-1990) ditetapkan berdasarkan pergantian Orde Lama dan dimulainya pemerintah Orde Baru yang memiliki paradigma berbeda. Tahap Pelembagaan III (1991-2011) ditetapkan berdasarkan penetapan Undang-Undang Republik Indonesia Nomor 9 Tahun 1990 Tentang Kepariwisataan oleh Presiden Suharto. Tahap kompromi ditetapkan dari tahun 2012 sampai sekarang, karena revisi Peraturan Daerah Provinsi Daerah Tingkat I Bali Nomor 3 Tahun 1991 menjadi Peraturan Daerah Provinsi Bali Nomor 2 Tahun 2012 Tentang Kepariwisataan Budaya Bali. 
Untuk lebih jelasnya berikut gambar 3.1 model perkembangan pariwisata Bali sebagai turimemorfosis:

\section{Gambar 3.1}

\section{Model Perkembangan Pariwisata Bali sebagai Turimemorfosis}

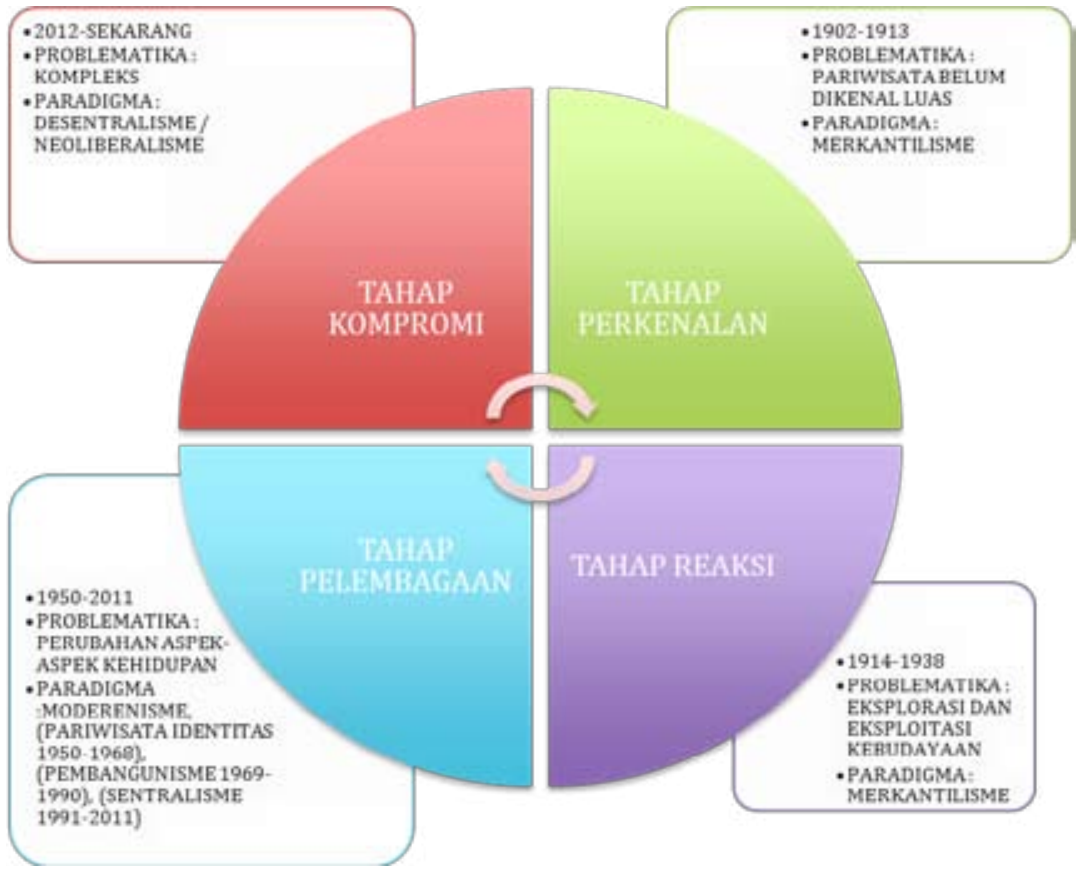

Sumber: Anom, dkk, 2016

Gambar 3.1 Model Perkembangan Parwisata Bali sebagai Turismemorfosis merupakan upaya untuk mengkaji secara diakronik seperti apa kepariwisataan di Bali berkembang dan mampu menjadi primadona seperti pada keadaan sekarang ini. Pada setiap periode memiliki diskursus, ketokohan, institusi penopang, paradigma dan problematika masing-masing. Perkembangan masing-masing periode jika diperhatikan secara mendalam memiliki pola-pola serupa namun berbeda bentuknya. Hal ini menunjukkan bahwa fenomena kepariwisataan tidak dapat terlepas dari faktor sejarah, faktor politik, faktor ekonomi, dan faktor sosial budaya. 


\subsection{Tahap Pengenalan, 1902-1913 \\ a. Diskursus}

Diskursus yang berkembang pada periode ini dapat dilihat dari upaya-upaya pemerintah Hindia Belanda untuk membangun daerah jajahannya dan memperbaiki citra setelah banyak peperangan dilakukan (Cribb, 1995; Boorstin, 1975; dalam Nugraha, 2006). Pada waktu itu aktivitas berlibur merupakan kegiatan yang menggembirakan dan sangat prospektif bagi kegiatan dunia usaha (Vickers, 1989 dalam Ardhana, 2015). Konsep kepariwisataan sudah muncul pada masa kolonial Belanda, namun belum disebut sebagai industri pariwisata (Wijaya, 2015).

\section{b. Institusi}

Dari sisi masyarakat Bali saat itu tidak menyadari dijadikan objek pada periode pengenalan. Belum disadari potensi-potensi pariwisata yang dimiliki dan masyarakat Bali justru merasa aneh dan secara lugu mulai berinteraksi meskipun pada titik-titik wilayah tertentu di Bali kebudayaan, alam, kepolosan dan keluguan orang Bali yang dirasakan oleh orang Eropa semakin membuat banyak orang Eropa tertarik datang ke Bali (Wawancara dengan Putra Agung, 2016).

\section{c. Tokoh}

Heer H. van Kol sebagai wisatawan yang pertama mengunjungi Bali menerbitkan buku di Leiden (Belanda) tahun 1902 dengan judul “Uit Onze Kolonien (Hanna, 1976). Setelah itu terjadi ketegangan politik di Bali dan meletus perang Puputan Badung di tahun 1906 dan perang Puputan Klungkung 1908.

Ketika Hindia Belanda sudah dinyatakan aman pada tahun 1912, pemerintah Hindia Belanda mulai membangun daerah jajahannya dan memperbaiki citra di mata dunia internasional. Terdapat pula pembuatcitra Bali pada masa itu W.O.J Nieuwenkamp (pelukis) dan Gregor Krause (dokter).

Krause antara tahun 1912-1914 memainkan peran utama dalam promosi pariwisata pulau Bali, ketika pada tahun 1920-an menerbitkan sebuah buku berisi hampir 400 foto, berjudul Bali 1912. Buku itu disambut hangat publik Eropa dan diterbitkan ulang berkali-kali. Dapat dipastikan salah satu kunci sukses buku 
ini terletak pada perhatian khusus juru foto dalam penampilan keindahan bentuk tubuh dan selera pada tema perempuan (dan lelaki) Bali misalnya di permandian (Krause, 1920; 1930; 1988; dalam Picard, 2006).

\section{c. Paradigma dan Problematika}

Paradigma yang dianut dalam tahap ini adalah merchan capitalism atau kapitalisme perdagangan (Ardhana, 2015). Suatu tradisi paham kapitalisme yang sudah diterapkan lama oleh pemerintah Hindia Belanda yaitu menekankan pentingnya agen perdagangan ekspor impor.

Problematika pariwisata Bali waktu itu pariwisata belum dikenal oleh masyarakat Bali. Pariwisata hanya dikenal oleh pemerintah Hindia Belanda dan perusahaan-perusahaannya serta sebagian kecil masyarakat Bali yang memiliki kedekatan dengan pemerintah berkuasa.

\subsection{Tahap Reaksi, 1914-1938 \\ a. Diskursus}

Bali mulai dirintis untuk pengembangan sektor pariwisata dengan mulai dibukanya akses transportasi darat (Putra Agung, dkk, 1994), laut dan udara di Singaraja (Damste, 1926 dalam Wijaya, 2015). Lontar dan warisan budaya lain diperlihatkan kepada kaum sarjana dan para pengunjung juga untuk mencegah penjualan kepada turis sebagai souvenir di Gedong Kirtya (Picard, 2006).

Terjadi kecaman cendekiawan Bali dalam majalah Surya Kanta tahun 1925 yang mengkritik Bali sebagai "museum hidup". Diharapkan Bali dapat melepaskan diri dari reputasi kolot yang melekat padanya tanpa adanya apa-apa yang mampu menimbulkan keingintahuan para wisatawan yang mencari eksotisme (tanpa nama, 1927 dalam Picard dalam 2006).

Di sisi lain, usaha untuk mengangkat kearifan lokal budaya Bali dilakukan oleh Raja Ubud, Cokorde Gde Raka Sukawati. Dalam misi kesenian ke Paris Colonial Exposition pada tahun 1931 (Foto 1), beranggotakan 51 seniman yang menunjukkan keahliannya di Anjungan Hindia Belanda. Bali semakin dikenal dengan pencitraan yang semakin baik di Eropa (Sendra, 2016). 


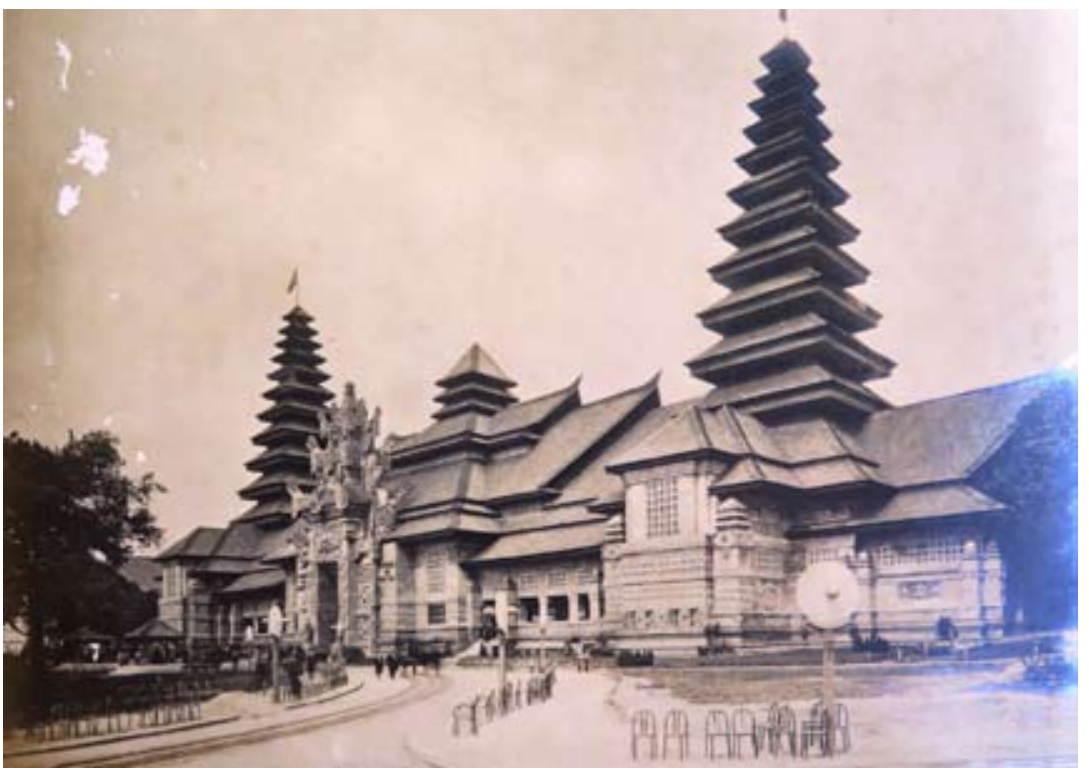

Foto 1. Anjungan arsitektur Bali di arena Paris Colonial Exposition (Foto Dok Puri Ubud).

\section{b. Institusi}

Didirikan Travel Agent di jalan Majapahit Nomor 2 Jakarta bernama Lissone Lindemend (LISIND) yang berpusat di Belanda pada tahun 1926, tahun 1928 berganti nama menjadi Nitour (Nederlansche Indische Touristen Bureau) dan bersama-sama travel agent KNILM memonopoli kegiatan berwisata di Indonesia (Yoeti, 1996). Di Bali telah muncul reaksi-reaksi yang bersifat komersial kehadiran wisatawan. Orang-orang Bali, Cina, Essex dan Huson serta KPM (Koninkelijke Paketvaar Matschappij) mendominasi muatan wisatawan (Raharjo dan Munandar, 1998).

\section{c. Tokoh}

Tokoh masa itu diantaranya Direktur Bali Institut yang didirikan tahun 1915, Rouffaer, Controlir Liefrinck dan Van der Tuk sebagai pendiri Gedong Kirtya (Pusat Lontar sampai saat ini masih berfungsi), Lekkerkerker, Moll, Flierhaar, Hoekstra, Stutterheim, Bernet-Kempers, A.J., Korn, tokoh tradisional yang memiliki ketertarikan terhadap pariwisata seperti Raja Ubud Cokorda Gde Raka Sukawati, tokoh-tokoh pengusaha seperti Jakob Minas asal Armenia, Andre Roosevelt, Thomas Cook asal Amerika Serikat, 
"Princess" Patimah perempuan Bugis yang mengaku sebagai bekas istri Raja Klungkung, Mrs. Mank (Ni K'tut Tantri) seorang Amerika yang mengelola bungalow di Kuta dan tokoh-tokoh seniman seperti Walter Spies bersama teman-temannya dalam melakukan komodifikasi beragam kesenian tradisional Bali untuk kepentingan wisatawan termasuk pemasarannya (Picard, 2006).

\section{d. Paradigma dan Problematika}

Paradigma merkantilisme dari pemerintah Hindia Belanda masih menjadi acuan pemerintah Hindia Belanda seperti pada tahap perkenalan. Pada tahap reaksi problematika kepariwisataan di Bali adalah dimulainya ekplorasi dan eksploitasi kebudayaan dengan paradigma merkantilisme. Di sisi lain harus diakui pada tahap reaksi sudah dimulai komodifikasi untuk kepentingan pariwisata yang menguntungkan seniman Bali. Peran Walter Spies bersama teman-temannya justru membangkitkan upaya revitalisasi terhadap seni tradisional.

Sampai akhirnya meletusnya perang dunia II pada tahun 1939, disusul dengan masa pendudukan Jepang 1942-1945 adalah masa suram pariwisata di Indonesia maupun di Bali (Raharjo dan Munandar, 1998). Masa pendudukan Jepang tidak dikaji dalam artikel ini. Selanjutnya dimulai tahun 1950 ketika kondisi Indonesia diangap mulai stabil pada zaman Presiden Soekarno yang dalam artikel ini dimasukkan dalam tahap pelembagaan periode pertama tahun 1950-1968.

\subsection{Tahap Pelembagaan I, 1950-1968}

\section{a. Diskursus}

Minat Presiden Soekarno terhadap pariwisata dapat dilihat dari keputusannya membangun Hotel Bali Beach tahun 1963 dan Lapangan Terbang Ngurah Rai (Raka Sukawati 2002, dalam Wijaya, 2015). Presiden Soekarno mulai berpikir tentang industri pariwisata ketika pemerintah Republik Indonesia pada waktu itu mengadakan Konfrensi Asia Afrika (KAA) di Bandung pada tahun 1955. Begitu banyak delegasi asing yang datang memerlukan akomodasi dan fasilitas pariwisata melahirkan ide cemerlang untuk pengembangan industri pariwisata di Indonesia. 


\section{b. Institusi}

Pasca-pengakuan kedaulatan Indonesia oleh Belanda, di Bali terjadi Indonesianisasi usaha-usaha dagang di Bali yang didominasi oleh pribumi dan warga keturunan etnis Cina (Ardhana, 2015). Tampaknya nuansa etnik ini berhasil dimunculkan untuk dapat membangkitkan semangat ekonomi di masyarakat (Suwitha, 2003 dalam Ardhana, 2015).

Di tingkat pusat lahir Yayasan Tourisme Indonesia (YTI), Dewan Tourisme Indonesia (DTI), dan Dewan Pariwisata Indonesia (DEPARI) (Kodhyat, 1996). Selain menjadi anggota YTI, DTI, dan DEPARI, orang-orang Bali yang tertarik dengan bisnis pariwisata juga memiliki institusi-institusi lokal di Bali. Seperti Gabungan Tourisme Bali yang berganti nama menjadi Bali Tour sebagai institusi yang mengkordinir berbagai toko, hotel dan sopir angkutan penumpang (Wawancara dengan Putra Agung, 2016). Tampak institusi-insitusi saat itu sarat dengan kepentingan ideologis politik dan cenderung saling bersaing serta berbenturan.

\section{c. Tokoh}

Pada periode ini selain pengusaha-pengusaha pariwisata dari etnis Cina dan Belanda (beberapa masih di Bali untuk berbisnis) lahir pengusaha-pengusaha lokal yang terdiri dari mantan pejuang kemerdekaan dengan paham nasionalis, paham komunis, penganut paham sosialis, dan keluarga berkasta atas. Presiden Soekarno merestui dua proyek besar saat itu yaitu perluasan Bandara Internasional Ngurah Rai dan Hotel Bali Beach di tahun 1963. Kedua proyek ini merupakan titik awal pembangunan Bali secara besar-besaran menjadi daerah pariwisata Indonesia bagian tengah yang kelak dilanjutkan oleh Presiden Suharto membangun kawasan Nusa Dua mulai tahun 1970-an (Putra, 2012).

Beberapa nama yang diperoleh adalah Pengurus Dewan Tourisme Bali yaitu Sutedja, Gde Puger dan Ny. Ida Mirah (Futtro, 2012), bersama seorang jurnalis asal Bali Nyoman S. Pendit, dan Nyoman Oka (Vickers 2013). Mulai terlihat generasi baru pariwisata yang intinya ingin bekerja memberikan pelayanan kepada wisatawan terutama di masa awal tahun 1970-an.

\section{d. Paradigma dan Problematika}

Periode ini memiliki paradigma pariwisata identitas dalam 
menyikapi pengaruh paradigma moderenisasi yang diupayakan berjalan harmonis. Dukungan besar Presiden Soekarno kepada Bali untuk pembangunan kepariwisataan diupayakan secara harmonis oleh pemerintah daerah agar dapat diwujudkan bersama para praktisi pariwisata Bali.

Problematika kepariwisataan di Bali masa itu adalah dimulainya perubahan-perubahan dan terbentur oleh iklim politis dan keamanan yang belum kondusif. Perbedaan ideologi politik yang ekstrem diantara elit dan grass root, pemberontakan Marsidi, meletusnya Gunung Agung, aksesibilitas, SDM dan pengelolaan menjadi problematika pariwisata Bali pada periode ini (Wawancara dengan Agung Mega, 2016).

\subsection{Tahap Pelembagaan II, 1969-1990}

\section{a. Diskursus}

Dalam pidato kenegaraannya yang pertama pada tanggal 16 Agustus 1968, Presiden Suharto menyatakan bahwa tahap pertama yang akan dilakukannya adalah memberikan perhatian khusus terhadap kepariwisataan Bali. Perencanaan pariwisata tetap disusun meneruskan Orde Lama (Vickers, 2013) dengan tangan besi oleh Presiden Suharto dan pemerintah Indonesia memesan penyusunan rencana induk kepada Societe Centrale four l'Equipment Touristique Outre-Mer (SCETO) (Picard, 2006). Di balik wacana industri pariwisata memang ada relasi-relasi kekuasaan antara Suharto dan Bank Dunia (Picard, 2006 dalam Wijaya, 2015).

Pada tahun 1973, di Hotel Denpasar, Jalan Diponegoro, Denpasar, digelar seminar Pariwisata Budaya untuk merumuskan identitas pariwisata Bali (Wawancara dengan Geriya, 2016). Pendapat lain mengatakan, upaya merumuskan pariwisata budaya sudah dimulai sejak tahun 1966 namun belum mampu menjadi advokasi karena kondisi politik waktu itu (Wawancara dengan Agung Mega, 2016). Ragam kabupaten yang ada Bali menemukan identitasnya yaitu pariwisata budaya. Pasti ada pariwisata alam, ada perkawinan budaya dan alam, namun sebagai identitas pokok adalah pariwisata budaya (Wawancara dengan Geriya, 2016).

Setahun setelahnya, identitas pariwisata budaya Bali sudah didapat dan menjadi contoh di Indonesia dan modal dasar pembangunan pariwisata Balikedepan, maka secara cepatDPRDBali mengesahkan menjadi Peraturan Daerah (Perda) Propinsi Tingkat 
I Bali Nomor 2 Tahun 1974 Tentang Pariwisata Budaya. Pariwisata budaya ditetapkan, dikumandangkan dan terimplementasi melalui perkembangan karya-karya seni selain daya tarik wisata yang terus bertambah (Wawancara dengan Geriya, 2016).

\section{b. Institusi}

Insitusipenopangadalahpemerintahpusat(polapembangunan top down) dan pemerintah daerah harus mengikutinya. Faktor politis memegang peran penting sebagai institusi yang memperkuat legitimasi pemerintah pusat. Khusus dalam kepariwisataan sudah mulai terbentuk banyak institusi-institusi yang terkait dengan usaha-usaha pariwisata.

Pada periode ini sudah tampak terjadi pergeseran fungsi institusi seperti subak karena sektor pertanian mulai ditinggalkan (Nehen 1994 dalam Raharjo dan Munandar, 1998). Institusi pendidikan pariwisata mulai tumbuh melahirkan SDM sebagai generasi yang akan berkarya pada periode berikutnya.

\section{c. Tokoh}

Gubernur Bali Soekarmen, Gubernur Bali Ida Bagus Mantra dan jajarannya saat itu (khususnya Dinas Pariwisata), tokoh-tokoh agama Hindu, akademisi dan para mantan pejuang yang eksis menggeluti sektor pariwisata, berperan dalam pembangunan kepariwisataan. Para investor besar asal Jakarta dan investor besar dari luar negeri yang memiliki jejaring dengan pemerintah pusat memiliki peran yang tidak kalah pentingnya.

Para "broker seni tradisional", pedagang acung, staf / karyawan hotel, dan mereka yang bergerak di sektor "jasa kecil-kecilan" dari era sebelumnya (1960an) menambah kehadiran pengusahapengusaha lokal yang sudah ada sebelumnya berbisnis pariwisata di Bali pada era ini. Kebanyakan dari mereka mampu menunjukkan eksistensi di tahun 1975-1990-an.

Terdapat fenomena baru yaitu mulai terjalin hubungan baik secara personal antar wisatawan mancanegara dengan orang Bali. Bentuknya antara lain perkawinan antar bangsa, pola anak asuh (anak orang Bali dibiayai oleh wisatawan mancanegara), sampai kepada orang Bali dipercaya untuk mengelola dana yang dimiliki wisatawan untuk membuka usaha di Bali (Wawancara dengan Sendra, 2016). Ketokohan selain dari para tokoh yang sudah eksis 
di tahun 1960an, terdapat generasi-generasi yang waktu tahun 1960an masih "junior", pada periode ini sudah mulai menunjukkan eksistensinya.

\section{d. Paradigma dan Problematika}

Periode ini memiliki paradigma pembangunanisme ketika sektor pariwisata mulai menjadi leading sector pembangunan ekonomi di Bali. Bahkan dalam skala nasional Bali tidak hanya dijadikan sebagai pusat daerah tujuan wisata Indonesia bagian tengah tetapi juga merupakan daerah primadona yang memberikan devisa nasional terbanyak di bidang pariwisata (Mantra, 1993; Nehen 1994 dalam Raharjo dan Munandar, 1998).

Problematika pariwisata Bali pada periode ini adalah terjadi banyak pergeseran-pergeseran seperti alih fungsi lahan, degradasi budaya, dan pemaksaan dari pemerintah pusat untuk selalu mengikuti kebijakan yang dipilih. Meskipun harus diakui bahwa pariwisata pada periode ini semakin menjanjikan secara ekonomi yang menarik minat generasi muda dari dalam maupun luar Bali.

\subsection{Tahap Pelembagaan III, 1991-2011}

\section{a. Diskursus}

Pada tahun 1990 ditetapkan Undang-Undang Republik Indonesia Nomor 9 Tahun 1990 tentang Kepariwisataan oleh pemerintah. Sebelumnya pada tahun 1989 dikampanyekan "Sadar Wisata" dengan gerakan Sapta Pesona. Pada tahun 1991 dicanangkan “Visit Indonesia Year" 1991 ketika Thailand, Singapura dan Malaysia sudah terlebih dahulu melakukannya (Picard, 2006).

Pada tahun 1991, Perda Nomor3 Tahun 1974 Tentang Pariwisata Budaya direvisi Perda Nomor 3 Tahun 1991 Tentang Pariwisata. Pada awal tahap ini sudah diketahui dan disadari bahwa terjadi ketidakseimbangan karena pembangunan sektor pariwisata (Hasil Wawancara dengan Geriya, 2016).

Krisis politik-ekonomi tahun 1998 yang terjadi ternyata membawa banyak perubahan di Indonesia termasuk Bali. Secara politik ditetapkannya Undang-Undang Otonomi Daerah Nomor 34 Tahun 1999 terutama di era presiden Megawati Soekarnoputri maka dimulailah babak baru kepariwisataan di Bali yang semakin kompleks (Megawati berperan besar dalam program Recovery Bali pasca-bom 12 Oktober 2002). 
Setelah pengesahan Undang-Undang Kepariwisataan Nomor 10 Tahun 2009 oleh Presiden Susilo Bambang Yudhoyono, pemerintah menetapkan Peraturan Pemerintah Nomor 50 Tahun 2011 Tentang Rencana Induk Pembangunan Kepariwisataan Nasional (Ripparnas) Tahun 2010-2025. PP Nomor 50 Tahun 2011 menetapkan Destinasi Pariwisata Nasional (DPN) dan Kawasan Strategis Pariwisata Nasional (KSPN) di Indonesia. Disusul dengan perencanaan MP3EI (Masterplan Percepatan dan Perluasan Pembangunan Ekonomi Indonesia) mencegah disparitas mencolok dari daerah-daerah di Indonesia (Kuncoro, 2012).

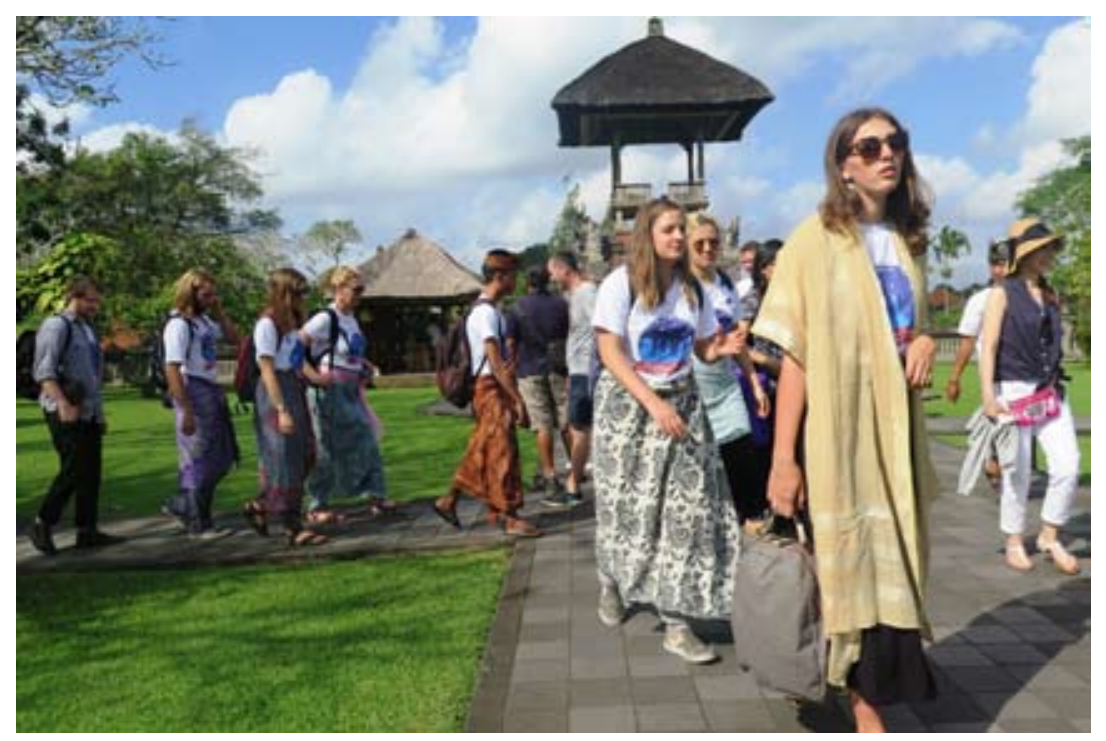

Foto 2. Kunjungan wisatawan asing ke Pura Taman Ayun, Mengwi (Foto Darma Putra)

\section{b. Institusi}

Daritahun1991-1998era kejatuhan OrdeBaru pemerintah pusat dan "kroninya" memberi pengaruh besar terhadap kepariwisataan Bali. Memasuki era reformasi sampai tahun 2011 pemerintah pusat bersama pemerintah daerah, perusahaan transnasional, perusahaan transinternasional, organisasi-organisasi kepariwisataan dan Lembaga Swadaya Masyarakat (LSM) berperan sebagai institusi penopang. Lahir begitu banyak elit-elit lokal yang duduk di kursi eksekutif dan legislatif sebagai implikasi dari otonomi daerah. Peran konglomerasi Jakarta dan kapital asing terasa semakin 
"memaksakan kehendak". Lahir sangat banyak institusi sebagai organisasi-organisasi kepariwisataan di Bali.

\section{c. Tokoh}

Secara nasional tokoh yang berperan dalam kepariwisataan di Bali pada tahapan ini adalah adalah Presiden Soeharto, Presiden Megawati dan Presiden Soesilo Bambang Yudhoyono, Menparpostel Soesilo Soedarman, Menbudpar Gde Ardika, Menpar Jro Wacik, Menparekraf Marie Pangestu, Gubernur Bali Ida Bagus Oka, Gubernur Bali Dewa Made Beratha, dan Gubernur Bali Made Mangku Pastika.

Tokoh-tokoh pariwisata perwakilan dari konglomerasi Jakarta dan jejaring kapital global yang memiliki kepentingan di Bali. Regenerasi dari para pejuang kemerdekaan yang melanjutkan bisnis pariwisata. Para tokoh-tokoh dari periode sebelumnya semakin berjaya pada periode ini. Banyak pengusaha Bali dan luar Bali yang meraih kesuksesan baik secara langsung berhubungan dengan sektor pariwisata maupun secara tidak langsung.

\section{d. Paradigma dan Problematika}

Era Presiden Megawati Soekarnoputri dan Presiden Susilo Bambang Yudhoyono memiliki paradigma sentralistik. Euforia masyarakat pasca-reformasi menjadi dilema antara kebebasan dan mematuhi peraturan. Namun, pemerintah pusat sebenarnya tetap mengendalikan daerah seperti pada era orde baru. Hanya karena situasi dan kondisi berbeda peran pemerintah pusat pada era kedua presiden tersebut menjadi tersamar. Jargonnya adalah optimalisasi potensi-potensi yang dimiliki daerah untuk pengembangan sesuai dengan cara dari pemerintah daerah sejalan dengan otonomi daerah.

Problematika pariwisata Bali pada periode ini adalah terjadi banyak perubahan sosial-budaya dan banyak variasi daya tarik wisata dan kreasi kesenian maupun produk-produk seperti kerajinan yang lahir namun ternyata banyak pula obyek wisata yang berjaya di tahun 1980an tidak mampu bertahan. Terbukti apa yang disampaikan Butler (1980) bahwa terjadi siklus hidup destinasi wisata yang suatu saat akan sampai pada tahap stagnation. 


\subsection{Tahap Kompromi, 2012-Sekarang}

\section{a. Diskursus}

Penetapan KSPN Besakih dan sekitarnya (mengulang kasus Bakrie Nirwana Resort tahun 1990-an), reklamasi Teluk Benoa (mengulang kasus reklamasi Serangan tahun 1988), Badung kelebihan kamar hotel, regulasi city hotel dan Villa, pariwisata massal yang menimbulkan kanibalisme, krisis air, admission fee, dan terjadi kekhawatiran orang Bali akan tersingkir karena pertumbuhan pariwisata. Selain itu terdapatnya juga diskursus positif seperti giatnya pengembangan desa wisata, wisata alam, sport tourism, wisata tirta dan jenis wisata lain yang mulai berkembang di daerah yang sebelumnya pariwisata tidak menjadi andalan.

Presiden terpilih periode 2014-2019 Joko Widodo tampaknya fokus terhadap pembangunan infrasruktur seperti aksesibilitas dan fasilitas di daerah-daerah. Akselerasi sektor pariwisata harus dilakukan untuk mampu mewujudkan target kunjungan wisatawan mancanegara pada tahun 2019, sebesar 20 juta orang (Yahya dalam Pitana, 2016).

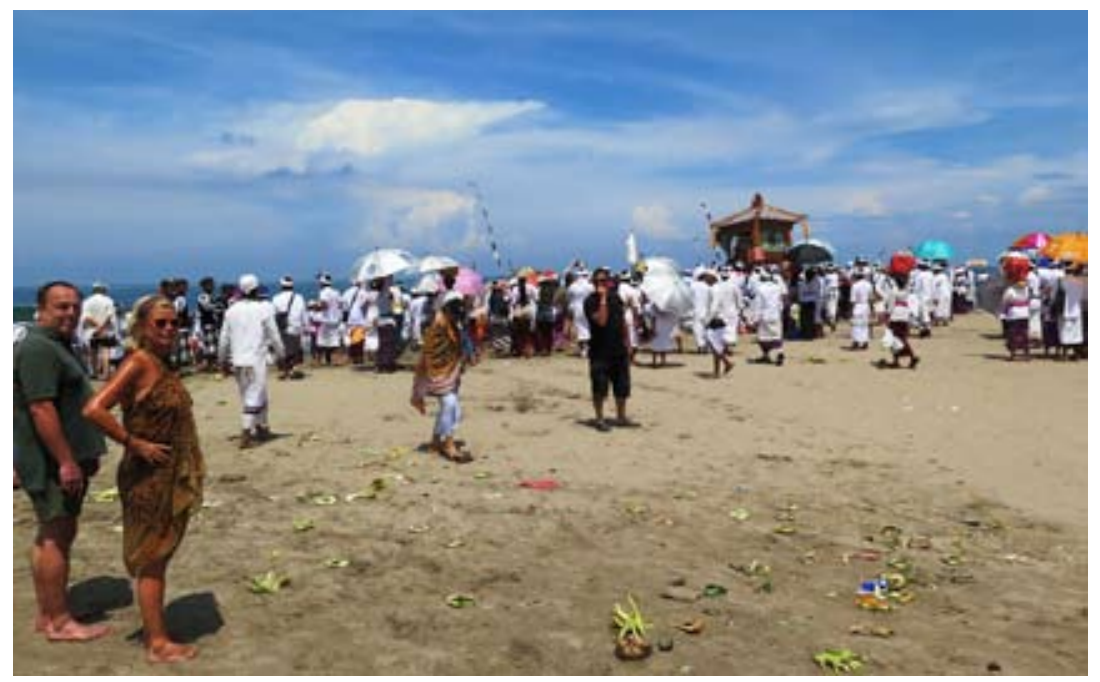

Foto 3. Wisatawan asing menyaksikan upacara prosesi di Pantai Petitenget, salah satu daya taruk budaya pariwisata Bali (Foto Darma Putra).

\section{b. Institusi}

Pemerintah pusat bersama pemerintah daerah, perusahaan transnasional, perusahaan transinternasional, organisasi-organisasi 
kepariwisataan, organisasi masyarakat, dan LSM. Di tingkat desa sangat bersemangat untuk pengembangan desa wisata, pengelolaan daya tarik wisata oleh desa adat dan ragam aktivitas wisata yang dikelola oleh masyarakat lokal dalam ragam bentuknya (desa dinas, desa pekraman, kelompok sadar wisata/Pokdarwis, badan pengelola atau badan usaha milik desa/Bumdes).

\section{c. Tokoh}

Pemerintah pusat, pemerintah daerah, elit-elit politik yang berprofesi sebagai pengusaha, kroni pemerintah pusat (inverstor Jakarta), investor asing (jejaring global), konglomerasi nasional dan internasional, partai politik berkuasa, birokrat lokal, regenerasi mantan pejuang kemerdekaan, pengusaha yang memiliki kedekatan dengan partai berkuasa, akademisi, tokoh adat, elit desa, elit lokal yang semula bertugas di luar daerah terjun dalam dunia pariwisata, pengusaha muda yang pada tahap sebelumnya (1969-1990) dari Bali maupunluar Bali telah sukses dan terus mengembangkan usahanya, pengusaha baru yang sebelumnya bekerja di sektor pariwisata (kapal pesiar, hotel dan restoran), kehadiran wirausahawan muda dari dan luar Bali yang mengandalkan kemampuan IT.

\section{d. Paradigma dan Problemtika}

Paradigma pada tahapini adalah desentralisme/neoliberalisme ketika jejaring konglomerasi nasional dan global berupaya semakin mengendalikan Bali atas dasar pertumbuhan ekonomi. Tidak ada jalan lain bagi masyarakat Bali untuk berkompromi meskipun ada riak-riak yang menginginkan perlawanan.

Problematika pariwisata Bali pada periode ini adalah sangat kompleks sebagai residu dari beroperasinya wacana-wacana yang ada sebelumnya. Artinya, akar geneologi yang berbasis pada praktik wacana (diskursif), institusi penopang, dan tokoh pendukung yang dipraktikkan di setiap periode (Foucault, 1954, dalam Arief, 2009).

\section{Prediksi Pembangunan Pariwisata Bali Masa Depan}

Tahap perkembangan pariwisata Bali masa depan memiliki paradigma transturisme sebagai sebuah penafsiran secara rasional namun tidak mengacu kepada paham positivistik yang kaku (Habermas, 1990; Hardiman, 1993 dalam Sudrajat 1998). Hegemoni (Gramsci dalam Bobbio 1988; Sassoon 1988a, 1988b dalam Alam, 
2014) dilakukan oleh institusi apa pun ketika mampu memberikan bukti nyata bahwa upaya dan usahanya dalam pariwisata telah menjadikan Bali semakin maju dan sejahtera. Akan terjadi sinergi ketokohan yang terlihat secara manifes saling mengisi namun sebenarnya memiliki resiko laten yang dapat meletus sewaktuwaktu jika kompromi dikesampingkan.

Pada titik ini diprediksi kebudayaan Bali akan tetap bertahan sebagai living culture. Meskipun sosial-religius masyarakat Bali sangat kuat, namun masyarakat Bali adalah masyarakat yang plural terbuka yang memberikan reaksi dan respon positif terhadap segala perubahan, khususnya perubahan sosial ekonomi (Sujana, 1994). Bahkan kesenian akan berkembang dengan pesatnya suatu hibridisasi (Beratha, dkk., 2016). Produk pariwisata tidak hanya mengandalkan pariwisata budaya. Pariwisata alam dan pariwisata buatan akan berkembang massif. Diperkirakan MICE dan New tourism seperti wisata belanja dan wisata keluarga (Murdiastuti, dkk., 2014) akan menjadi trend pariwisata Bali di masa depan.

\section{Kesimpulan}

Dari penelitian yang telah dilakukan dan dituangkan dalam tulisan ini maka diperoleh kesimpulan sebagai berikut:

Pertama, perkembangan kepariwisataan Bali sebagai turismemorfosis tidak dapat terlepas dari pengaruh luar mulai dari tahapan pengenalan sampai pada tahapan kompromi yang dihadapi oleh orang Bali.

Kedua, paradigma transturisme di masa depan berdimensi etis sebagai hasrat bersama para stakeholders untuk saling menguatkan (menyama braya). Sebagai sebuah gerakan transturisme berpretensi memfasilitasi aspirasi para aktor untuk saling sharing modal dan bersifat adaptif terhadap berbagai tipikal/model pariwisata ditengah kemajuan informasi dan teknologi (IT), dan beragam intervensi dengan keyakinan Bali masih memiliki kekuatan internal yaitu tradisi dan adat-istiadat yang dijiwai oleh agama Hindu.

\section{Ucapan Terima Kasih}

Kami mengucapkan terima kasih kepada pihak-pihak yang telah membantu terselesaikannya penelitian ini yaitu Rektor Universitas Udayana, Ketua Lembaga Penelitian dan Pengabdian kepada Masyarakat, Universitas Udayana, Dekan Fakultas Pariwisata 
Universitas Udayana, para informan antropolog I Wayan Geriya, dan Sejarawan Prof. Anak Agung Putra Agung serta para informan lain yang tidak dapat kami sebutkan satu persatu.

\section{Daftar Pustaka}

Alam, B. 2014. Antropologi dan Civil Society: Pendekatan Teori Kebudayaan. Antropologi Indonesia. Google Scholaar Link.

Anom, I Putu, Saptono Nugroho, I Gst. Ag. Oka Mahagangga. 2016. "Problematika Pariwisata Bali, Membangun Paradigma Pariwisata Bali Masa Depan". Denpasar:LaporanHasilPenelitian Hibah Unggulan Udayana-LPPM Universitas Udayana.

Ardhana, I Ketut. 2015. Nasionalisasi Perusahaan : Peralihan dari Perusahaan Belanda ke Perusahaan Lokal di Bali. AAA. Dewi Girindrawardani dan Slamat Trisila (ed.). Membuka Jalan Keilmuan, Kusumanjali 80 Tahun Prof. DR. Anak Agung Gde Putra Agung, S.U. Denpasar: Pustaka Larasan

Arief, Budiman. 2009. Pengetahuan dan Metode: Karya-karya Penting Michel Foucault. Yogyakarta: Jalasutra.

Beratha, N. L Sutjiati., Sukarini, N. W., \& Rajeg. 2016. I. Hibridisasi Seni Kerajinan Patung di Desa Kedisan, Bali. Jurnal Kajian Bali (Journal of Bali Studies), 6(2), 177-194. Google Scholaar Link.

Bungin, Burhan. 2003. Metodologi Penelitian Kualitatif. Jakarta : Raja Grafindo Persada.

Butler, R. W. (1980). The concept of a tourist area cycle of evolution: implications for Management of Resources. The Canadian Geographer 24(1), 5-12.

Fidler, Roger. 2003. Mediamorfosis: Memahami Media Baru. Yogyakarta: Bentang Budaya.

Futtro, Tiko Dwiantoro. 2012. "Peran Dewan Turisme Indonesia Dalam Menunjang Pariwisata di Indonesia (1957-1965)". Penelitian yang Tidak Dipublikasikan. Depok: PS Ilmu Sejarah, Fakultas Ilmu Pengetahuan Budaya, Universitas Indonesia.

Geriya, I Wayan. 2003. Pola Partisipasi dan Strategi Perjuangan HakHak Komuniti Lokal dalam Pembangunan Pariwisata di Era Multikultural (Perspektif Pariwisata Budaya Bali) dalam "Guratan Budaya dalam Perspektif Multikultural, Persembahan Kepada Prof. Ngurah Bagus". Denpasar : Fakultas Sastra Unud.

Giddens, Anthony. 1984. The Constitution of Society: Outline of the 
Theory of Structuration, Berkeley and Los Angeles: University of California Press.

Giddens, Anthony. 2010. Metode Sosiologi: Kaidah-kaidah Baru, Yogyakarta: Pustaka Pelajar.

Hanna, W.A. 1976. Bali Profile, People, Evens, Circumstances. New York: American Universities Field Staff.

Hardiman, F. Budi. 2012. Melampaui Positivisme dan Modernitas: Diskursus Filosofis tentang Metode Ilmiah dan Problem Modernitas. Yogyakarta: Kanisius.

Karsidi, R. (2001). Paradigma Baru Penyuluhan Pembangunan dalam Pemberdayaan Masyarakat. MediaTor (Jurnal Komunikasi), 2(1), 115-125.

Kodhyat, H. 1996. Sejarah Pariwisata dan Perkembangannya di Indonesia. Jakarta: Gramedia Widiasarana Indonesia.

Kuncoro Mudrajat. 2012. Perencanaan Daerah, Bagaiamana Membangun Ekonomi Lokal, Kota dan Kawasan? Jakarta: Salemba Empat.

Miles dan Hubberman. 1992. Analisis Data Kualitatif. Jakarta: UI Press

Moleong, Lexy. 2005. Metodelogi Penelitian Kualitatif. Remaja Rosda Karya, Bandung.

Murdiastuti, Anastasia, Hemanto Rohman, dan Suji. 2014. Kebijakan Pengembangan Pariwisata Berbasis Democratic Governance. Surabaya: Pustaka Radja

Nordholt, H.S., Bambang Purwanto, Ratna Saptari. 2008. “Memikir Ulang Histiografi Indonesia" dalam Nordholt, H.S., Bambang Purwanto, Ratna Saptari (ed). Perspektif Baru Penulisan Sejarah Indonesia. Jakarta: Yayasan Obor Indonesia, KITLV dan Pustaka Larasan.

Nugraha, Iskandar P. 2006. Buku Panduan Wisata Kolonial di Indonesia (Bagian dari "Politics Seeing' Belanda?"). Jurnal Kajian Budaya Volume 3 Nomor 5 Januari 2006. Denpasar: PS. S2 Kajian Budaya-Universitas Udayana.

Peraturan Daerah Propinsi Tingkat I Bali Nomor 3 Tahun 1974 tentang Pariwisata Budaya. Badung: Pemerintah Daerah Propinsi Tk. I Bali.

Peraturan Daerah Propinsi Daerah Tingkat I Bali Nomor 3 tahun 1991 Tentang Pariwisata Budaya. Denpasar: Pemerintah Propinsi Tk. I Bali.

Peraturan Pemerintah Republik Indonesia Nomor 50 Tahun 2011 
tentang Rencana Induk Pembangunan Kepariwisataan Nasional Tahun 2010-2025. Jakarta : Setneg. RI.

Peraturan Daerah Provinsi Bali Nomor 2 Tahun 2012 tentang Kepariwisataan Budaya Bali. Denpasar: Setda Provinsi Bali.

Picard, Michel. 2006. Bali: Pariwisata Budaya dan Budaya Pariwisata (terj.) Jakarta: KPG (Kepustakaan Populer Gramedia)

Pitana, I Gde. 2002. "Pariwisata, Wahana Pelestarian Kebudayaan dan Dinamika Masyarakat Bali". Pidato Pengukuhan Guru Besar bidang Sosial Pariwisata. Denpasar: Universitas Udayana

Pitana, I Gde. 2016. "Strategi Pembangunan Pariwisata Indonesia". Prosiding Seminar Nasional Bali Up Date 2016. Denpasar: Pusat Kajian Bali Universitas Udayana dan Pemprov. Bali

Putra Agung, A.A.Gde, Drs. FX Soenaryo, Drs. Ida Agus Sidemen. Sejarah Sosial Kota Singaraja. Jakarta: Depdikbud, Direktorat Sejarah dan nilai Tradisional, Proyek Invetarisasi dan Dokumentasi Sejarah Nasional, 1984

Putra, I Nyoman Darma. 2012. Pasangan Pionir Pariwisata Bali. Denpasar: Jagatpress.

Raharjo, Supratikno dan Agus Aris Munandar. 1998. "Dampak Pariwisata Terhadap Kebudayaan Bali". Susanto Zuhdi (ed). Sejarah Kebudayaan Bali: Kajian Pengembangan dan Dampak Pariwisata. Jakarta : Departemen Pendidikan dan Kebudayaan RI

Sarup, Madan. 2011. Poststrukturalisme dan Posmodernisme, Yogyakarta: Jalasutra

Sendra, I Made. 2016. "Paradigma Kepariwisataan Bali Tahun 1930an: Studi Genealogi Kepariwisataan Budaya", Jurnal Kajian Bali (Journal of Bali Studies), 6(2), 97-124.

Sudrajat, A., \& UNY, P. I. S. F. 1998. Jurgen Habermas: Teori Kritis dengan paradigma komunikasi. Url: http://staff. uny.ac. id/system/ files/penelitian/Ajat\% 20Sudrajat,\% 20Prof.\% 20Dr, 20.

Sugiharto, Bambang. 1996. Postmodernisme: Tantangan bagi Filsafat. Yogyakarta: Kanisius

Sugiyono. 2005. Memahami Penelitian Kualitatif. Bandung: Alfabeta.

Sujana, N. 1994. Manusia Bali di Persimpangan Jalan. Dalam Dinamika Masyarakat dan Kebudayaan Bali. Denpasar: Offset Bali Post.

Undang-Undang Republik Indonesia Nomor 10 Tahun 2009 tentang Kepariwisataan. Jakarta : Kementerian Pariwisata RI. 
Undang-Undang Republik Indonesia Nomor 9 Tahun 1990 tentang Kepariwisataan. Jakarta: Deparpostel RI.

Wijaya, Nyoman. 2015. “Lintas Budaya Global Lokal di Bali Dalam Perspektif Sejarah". dalam AAA. Dewi Girindrawardani dan Slamat Trisila (ed.). Membuka Jalan Keilmuan, Kusumanjali 80 Tahun Prof. Dr. Anak Agung Gde Putra Agung, S.U. Denpasar: Pustaka Larasan.

Wijayanto, E. 2013. Memetika sebagai Studi Kebudayaan Berbasis Evolusi. MELINTAS, 29 (1).

Yoeti, A. Oka. 1996. Pengantar Ilmu Pariwisata. Bandung: PT Angkasa. 